Available online at http://www.ajol.info/index.php/njbas/index Nigerian Journal of Basic and Applied Science (June, 2015), 23(1): 81-84 DOI: http://dx.doi.org/10.4314/njbas.v23i1.12

\title{
Comparative Study of Antioxidant Activities of the Leaves and Stem of Ipomoea aquatica Forsk (Water Spinach)
}

\author{
${ }^{* 1}$ K.J. Umar, ${ }^{1}$ M.J. Muhammad, ${ }^{1}$ N.A. Sani, 2 S. Muhammad and ${ }^{3}$ M.T. Umar \\ 1Department of Pure and Applied Chemistry, Usmanu Danfodiyo University, P.M.B 2346, Sokoto, Nigeria. \\ 2Department of Chemistry, Sokoto State University, P.M.B. 2134, Sokoto, Nigeria. \\ 3lbrahim Badamasi Babangida University, Lapai, Nigeria \\ [Corresponding author: Email kjumar@gmail.com; $\mathbf{8}:+2347034845355]$
}

\begin{abstract}
Leaves and stem extracts of Ipomoea aquatic Forsk were analysed for their antioxidant activities. Folin-Ciocalteu and $\mathrm{AlCl}_{3}$ methods were used to quantify total phenolic and flavonoid contents while 1,1-diphenyl2-picryl hydrazyl (DPPH) radical assay was used to examine the antioxidant activity of the extracts. The respective total phenolic and flavonoid contents of the stem $\left(18.00 \pm 1.20\right.$ and $20.00 \pm 1.40 \mu \mathrm{g}$ Catechin equivalent, CEQ g ${ }^{-1}$ DW) show no significant $(p>0.05)$ difference when compared to leaves $\left(16.00 \pm 1.10\right.$ and $30.00 \pm 2.1 \mu \mathrm{g} \mathrm{CEQ} \mathrm{g} \mathrm{g}^{-1}$ DW). In DPPH scavenging assay, the reference standard i.e. vitamin $\mathrm{C}\left(\mathrm{IC}_{50}=0.0660 \mu \mathrm{g} / \mathrm{ml}\right)$ had significantly $(p<0.05)$ higher scavenging activity than the stem $\left(\mathrm{IC}_{50}=35.96 \mu \mathrm{g} / \mathrm{ml}\right)$ which in turn is significantly higher $(\mathrm{p}<0.05)$ than the leaves $\left(I_{50}=176.92 \mu \mathrm{g} / \mathrm{ml}\right)$. From the results it can be concluded that stem and leaves of Ipomoea aquatica had similar antioxidants activity.
\end{abstract}

Keywords: Ipomoea aquatica, antioxidant, DPPH Assay, Scavenging activity, phenolic, flavonoid.

\section{INTRODUCTION}

Antioxidants are substances that are capable of preventing cells from damages caused by unstable molecules known as free radicals (Hamid et al., 2010). Antioxidants thus interact with and stabilize free radicals and may prevent some of the damages free radicals may otherwise cause. The application of synthetic antioxidants such as butylated hydroxyl toluene (BHT), butylated hydroxyl anisole (BHA), tertiary butylated hydroquinone and gallic acid esters have been restricted as they are suspected to cause or prompt adverse health effect (Maurya and Singh, 2010). The importance of substituting these antioxidants with those of natural origin has therefore become a priority in recent years. Thus, phytochemicals have been isolated from plant materials such as bark, leaves, stem, roots, fruits, seeds, fruit rid, flower and whole plants (Gobalakrishnan et al. 2013).

Some medicinally important plants have been effectively used against nose bleed, reduction of blood sugar levels and as antibiotic against Escherichia coli, Pseudomonas aeruginosa and Bacillus subtilis (Hamid et al., 2011). Bioactive compounds are usually accumulated as secondary metabolites in all plant cells; however, their concentrations could vary from one plant part to another (Gobalakrishnan et al., 2013).

Water spinach (Ipomoea aquatica Forsk) belongs to the family Convolvulaceae. It is a tender trailing or floating perennial aquatic plant found on moist soil along the margins of fresh water and is being cultivated as an edible green leafy vegetable in Hong Kong, Taiwan, China and Nigeria (Prasad et al., 2005; Umar et al., 2007; James et al., 2009).

It was therefore the aim of the present study to compare the antioxidant activities of the leaves and stems of $I$. aquatica with a view to understanding which of the two has better medicinal antioxidant activities.

\section{Materials and Methods \\ Plant Materials}

Fresh Ipomoea aquatica Forsk was obtained from a local market in Sokoto metropolis. It was authenticated at the herbarium, Department of Biological Sciences of the Usmanu Danfodiyo University Sokoto. The leaves and stems were cleaned with water and dried in a hot air oven for $36 \mathrm{~h}$ at $48^{\circ} \mathrm{C}$. The leaves and stems were subsequently powdered using a mortar and pestle.

\section{Sample Preparation}

Thirty grammes each of the dry powdered and stems of $I$. aquatica were extracted with $200 \mathrm{~cm}^{3}$ of $95 \%$ methanol for $6 \mathrm{~h}$ at $60^{\circ} \mathrm{C}$ using a soxhlet apparatus. The extracts were then filtered through Whatman No. 41 filter paper to remove suspended particles. The filtrates were concentrated under vacuum in a rotary evaporator at $40^{\circ} \mathrm{C}$. 


\section{Determination of Total Phenolic Flavonoid and Free Radical Scavenging Activity}

The total phenolic compounds were determined by Folin-Ciocalteu method according to Ragazzi and Veronese (1973). For flavonoid, aluminium (III) chloride method as described by Lamaison and Carnet (1990) was used. The Free radical scavenging activity was determined using 1,1-diphenyl-2-picryl hydrazyl (DPPH) free radical assay as described by Adesegun et al. (2008).

\section{Statistical Analysis}

Analyses were carried out in triplicates of each set up and results expressed as mean \pm standard error of mean. Statistically significant difference $(p<0.05)$ was determined using Student's t-test. All data were analyzed using Statistical Package for the Social Sciences (SPSS version 15.0).

\section{RESULTS}

The total phenolic and flavonoid contents of $I$. aquatica are presented in Table 1. From the results, both the phytochemicals in the stem show no significance $(p>0.05)$ difference from the respective leaves values.

The free radical scavenging activities of the extracts of the plant are presented in Table 2. The stem had significantly $(\mathrm{p}<0.05)$ higher scavenging activity $\left(\mathrm{IC}_{50}=\right.$ $35.96 \mu \mathrm{g} / \mathrm{ml})$ than the leaves $\left({ } C_{50}=176.92 \mu \mathrm{g} / \mathrm{ml}\right)$ at all concentrations. All the samples have significantly $(p<0.05)$ lower level of activities when compared to reference standard (ascorbic acid) at concentrations of $25-100 \mu \mathrm{g} / \mathrm{ml}$.

\section{DISCUSSION}

Phenolic compounds are a class of antioxidant agents which act as free radical terminators and also involved in the retardation of oxidative degradation of lipids (Pourmorad et al., 2006). Our findings of higher levels of phenolic compounds in the stem methanolic extracts agrees with the findings of James et al. (2009) who reported values of $0.35 \pm 0.07 \%$ for the stem and $0.31 \pm 0.01 \%$ for the leaves. In a similar study by Huang et al. (2005), the stem phenolic compounds $(37.40 \pm 1.70 \mu \mathrm{mol} / \mathrm{g}$ D.W. $)$ were reported to be higher than that of the leaves $(27.60 \pm 1.57 \mu \mathrm{mol} / \mathrm{g}$ D.W. $)$. According to Maurya and Singh (2010), the antioxidant activity of plants might be due to the presence of phenolic compounds in them. Thus, the presence of phenolic compounds in the leaves and stem of $I$. aquatica may be an added value to its nutritional and medicinal potential.

Table 1: Total Phenolic and Flavonoid Contents of $I$. aquatica Leaves and Stem ( $\mu \mathrm{g} \mathrm{CEQ} \mathrm{g-1} \mathrm{DW}$ )

\begin{tabular}{lcc}
\hline Parameter & Leaves & Stem \\
\hline Total phenolic & $16.00 \pm 1.10$ & $18.00 \pm 1.20$ \\
Total flavonoid & $30.00 \pm 2.10$ & $20.00 \pm 1.40$ \\
\hline
\end{tabular}

Table 2: Free radical scavenging activity of $I$. aquatica leaves, stem and standard ascorbic acid.

\begin{tabular}{cccc}
\hline Concentration $(\boldsymbol{\mu} \mathbf{g} / \mathrm{ml})$ & \multicolumn{3}{c}{ Scavenging Activity $(\mathbf{( \% )})^{* *}$} \\
\cline { 2 - 4 } & Stem & Leaves & Ascorbic acid \\
\hline 25 & $46.1 \pm 0.28^{*}$ & $26.6 \pm 0.33^{*}$ & $89.5 \pm 0.43^{*}$ \\
50 & $54.9 \pm 0.01^{*}$ & $34.1 \pm 0.16^{*}$ & $97.4 \pm 0.16^{*}$ \\
75 & $64.7 \pm 0.12^{*}$ & $36.1 \pm 0.16^{*}$ & $98.0 \pm 0.03^{*}$ \\
100 & $74.0 \pm 0.17^{*}$ & $37.9 \pm 0.16^{*}$ & $99.0 \pm 0.01^{*}$ \\
$\mathrm{IC}_{50}$ & 35.96 & 176.92 & 0.0660 \\
\hline
\end{tabular}

The data are Mean \pm Standard error of mean of triplicate determinations; ${ }^{*}$ significantly different at $\mathrm{P}<0.05 .{ }^{* *} \mathrm{I}=$ inhibition of $\mathrm{DPPH}$

The trend of flavonoid accumulation in stem and leaves is consistent with the findings of Huang et al. (2005) where the leaves contained higher flavonoid than the stem. Previous findings have suggested that flavonoids carry out antioxidant action through scavenging or chelating process, hence, play a preventive role in cancer and heart disease (Ogbunugafor et al., 2011). Thus, the occurrence of flavonoids in I. aquatica extracts may similarly improve the economic and health potentials of the vegetable as reports have shown that 
the vegetable is cultivated commercially for nutritional and medicinal applications (Prasad et al., 2005). The observed differences in the concentrations of phenolic and flavonoid contents of the leaves and stem is in agreement with a previous study (Gobalakrishnan et al., 2013) which suggested that bioactive compounds are normally accumulated as secondary metabolites in all plant cells but their concentration could vary in different parts of the plant. According to Hemm et al. (2004), phenolics and flavonoids synthesis in plants is influenced by environmental factors, leaf maturity, plant age etc. Light intensity regulates not only plant growth and development, but also the biosynthesis of both primary and secondary metabolites Ghasemzadeh et al. (2010). Phenolic biosynthesis requires light or is enhanced by light, and flavonoid formation is absolutely light dependent and its biosynthetic rate is related to light intensity (Xie and Wang, 2006).

The antioxidant potential of phytochemicals is studied using the quenching of free radicals. The $I$. aquatica leaves and stem was further highlighted by the quenching of DPPH - free radicals, which is a proton free radical commonly used to determine the free radical scavenging power of antioxidants (Adesegun et al., 2008). The decrease in absorbance of DPPH $-I$. aquatica extracts mixture in this study which measured the extent of radical scavenging activity of the extracts supported the findings of AsokKumar et al. (2009). In the present study, it was observed that the stem extract exhibited better scavenging activity than the leaves. This observation is consistent with the findings of Huang et al. (2005). Similar results have also been reported by James et al. (2009). The stem extract had better scavenging activity $\left(\mathrm{IC}_{50}=35.96 \mu \mathrm{g} / \mathrm{ml}\right)$ than the leaves $\left(I C_{50}=176.92 \mu \mathrm{g} / \mathrm{ml}\right)$. The higher scavenging activity of the stem may be as a result of the increased phenolic contents of the stem compared to the leaves. Olukemi et al. (2005) has reported a strong relationship between phenolic content and antioxidant activity in selected fruits and vegetables. Phenolic compounds are the major contributors to antioxidant activity (Hamid et al., 2011; Zainol et al., 2003). This was confirmed in this study whereby the stem extract with more phenolic compounds exhibited greater antioxidant activity. The extracts had significant effects on the DPPH radical.

\section{CONCLUSION}

In the current study, I. aquatica leaves and stem were compared in terms of their antioxidant properties. The leaves and stem had antioxidant properties which were higher in the stem extract although not significant ( $p>$ 0.05 ); and this suggest $I$. aquatica stem and leaves had similar antioxidant activities and hence may play a role in the treatment of free radical related disorders.

\section{REFERENCES}

Adesegun, S.A., Elechi, N.A. and Coker, H.A.B. (2008). Antioxidantactivities of methanolic extracts of Sapium elliticum. Pakistan Journal of Biological Sciences, 11: 453-47.

AsokKumar, K., Maheswari, M.U., Sivashanmugan, A.t., Subhadra, D.V., Subhashini, N. and Ravi, T.K. (2009). Free radical scavenging and antioxidant activities of Glinus oppsitifollius (Carpet Weed) using different in Vitro assay systems. Pharmaceutical Biology, 47: 474-482

Ghasemzadeh, A., Jaafar, H.Z.E., Rahmat, A., Wahab, P.E.M. and Abd-Halim, M.R. (2010). Effects of light Intensities on Total Phenolics and Flavonoid Synthesis and Anti-oxidant Activities in Young Ginger Varieties (Zingiber officinale Roscoe). International Journal of Molecular Sciences, 11: 3885-3897

Gobalakrishnan, R., Kulandailu, M., Bhuvaneswari, R., Kandavel, D. and Kannan, L. (2013). Screening of Wild Plant Species for Antibacterial Activity and Phytochemical Analysis of Tragia involucrate L. Journal of Pharmaceutical Analysis, 3(6): 460-465

Hamid, A.A., Aiyelaagbe, O.O., Usman, L. A., Ameen, O. M. and Lawal, A. (2010). Antioxidants: Its medicinal and pharmacological applications. African Journal of Pure and Applied Chemistry, 4(8): 142-151.

Hamid, K., Ullah, M.O., Sultan, S., Howlader, Md. A., Basak, D., Nasrin, F. and Rahman, R.R. (2011). Evaluation of the Leaves of Ipomoea aquatica for its Hypoglycemic and Antioxidant Activity. Journal of pharmaceutical Sciences and Research, 3(7): 1330-1333.

Hemm, M.R., Rider, S.D., Ogas, J., Murry, D.J., Chapple, C. (2004). Light Induces Phenylpropanoid Metabolism in Arabidopsis Roots. Plant Journal, 38: 765-778

Huang, D-J., Chen, H-J., Lin, C-D., and Lin, Y-H. (2005). Antioxidant and Antiproliferative activities of Water Spinach (Ipomoea aquatica Forsk) Constituents. Botanical Bulletin of Academia Sinica, 46: 99-106.

James, O., Nnacheta, O.P. Wara, H.S. and Aliyu, U.R. (2009). In vitro and in vivo studies on the antioxidative activities, membrane stabilization 
and cytotoxicity of water spinach (Ipomoea aquatic Forsk) from Ibaji ponds, Nigeria. International Journal of PharTech Research, 1: $474-482$.

Lamaison, J.L.C. and Carnet, A. (1990). Contents in main flavonoid compounds of Crataegus monogynaJacq. and Crataegus laevigata (Poiret) D.C. flowers at different development stages. Pharmaceutica Acta Helvetica, 65: 315-320.

Maurya, S. and Singh, D. (2010). Quantitative Analysis of Total Phenolic Content in Adhatoda vasica Nees Extracts. International Journal of PharmTech Research, 2(4): 2403-2406

Ogbunugafor, H.A., Eneh, F.U., Ozuma, A.N., IgwoEzipke, M.N., Opkuzor, J., Igilo, I.O., Adenekan, S.O. and Onyekwelu, O.A. (2011). Physicochemical and Antioxidant Properties of Moringa oleifera Seed Oil. Pakistan Journal of Nutrition, 10(5): 409-414.

Olukemi, O.A., J.M. Oluseyi, I.O. Olukemi and S.M. Olutoyin, (2005). The use of selected Nigerian natural products in management of environmentally induced free radical skin damage. Pakistan Journal of Biological Sciences, 8: 1074 1077.

Pourmorad, F., Hosseinimehr, S.J. and Shahabimajd, N. (2006). Antioxidant activity, phenol and flaconoids content of some selected Iranian plants. African Journal of Biotechnology, 5: 11421145.

Prasad, K.N., Divakar, S., Shivamurthy, G.R. and Aradhya, S.M. (2005). Isolation of a free radicalscavenging antioxidant from Water Spinach (Ipomoea aquatica Forsk). Journal of the Science of Food and Agriculture, 85: 1461-1468.

Ragazzi, E. and Veronese, G. (1973). Quantitative analysis of phenolics compounds after thin-layer chromatographic separation. Journal of Chromatography, 77: $369-375$.

Umar, K.J., Hassan, L.G., Dangoggo, S.M. and Ladan, M.J. (2007). Nutritional Composition of Water Spinach (Ipomoea aquatica Forsk) Leaves. Journal of Applied Sciences, 7(6): 803-809.

Xie, B.D. and Wang, H.T. (2006). Effects of light spectrum and photoperiod on contents of flavonoid and terpene in leaves of Ginko bilobaL. Nanjing Forestry University, 38: 51-54

Zainol, M.K., Abd-Hamid, A., Yosuf, S. And Muse, C. (2005). Antioxidant and total phenolic compounds of leaf, root and petiole of four accessions of Cantella asiatica (L.) Urban. Food Chemistry, 81: 575-581. 